\title{
RESTORATION OF HUMAN RIGHTS OF THE PALESTINIAN PEOPLE: THE ROLE OF THE UNITED NATIONS AND THE SUPERPOWERS
}

\author{
Sardar MUHAMMAD
}

The Palestinian people are in a state of dislocation and dispersion for the last 33 years. Their statelessness has denuded them of human rights, and their subjugation/dependence has deprived them of the commonly accepted standards of civilized being and living. They live in perpetual dehumanizing conditions, and are under constant danger for their lives. The fruits of human civilizational, social, and political progress as expressed by the world community in the form of the Charter of the United Nations and the Universal Declaration of Human Rights, have failed to reach them.

The world community has reached a consensus on the common standards of acceptable international conduct by using the forum of UN and expects this body to enforce these measures for all peoples of all nations. The superpowers - the United States and the Soviet Union - as the repositories of the greatest military and economic power and thereby the wielders of dominant influence in world affairs, continue to play an important role in setting the tone of the outcome of deliberations, debates and discussions of UN organs. By and large, it is their power and influence, both within and without the folds of the UN, that determine the effectiveness of the decisions and resolutions of the various organs of the world body. Their policies of economic and military aid, and diplomatic and political support help or hinder the implementation of consensus of world community on human rights.

Against the above backdrop, this article is an attempt to describe and analyse the extent of deprivation of the human 
rights of the Palestinian people and the policies of Israel in this regard. The foregoing objective is intended to be achieved by focussing on:

i. standards of civilized being as decided upon by the world community in the UN Charter and the Universal Declaration of Human Rights, and the efforts of the organs of the UN to implement them with regard to the Palestinian people;

ii. the role of the superpowers in providing and/or forestalling human rights to the Palestinian people, both within and without the UN; and

iii. to suggest ways and means for the removal of obstructions in the way of the realisation of human rights for the $\mathrm{Pa}$ lestinian people.

\section{The Problem}

\section{i. The Palestinian People}

The Palestinian people are in "diaspora" since the establishment of the state of Israel in 1948. Britain got the mandate over Palestine from the League of Nations on July 24, 1922. ${ }^{1}$ Earlier, on November 2, 1917, through the Balfour Declaration, she had promised the Zionists "the establishment of a national homeland for the Jewish people", ${ }^{2}$

Britain, as the mandatory power, facilitated large scale Jewish settlement in Palestine. At the time of the issuing of the Balfour Declaration, the Jewish population in Palestine numbered some 56,000 against an Arab population of 600,000. At the end of 1946 Palestine contained 1,887,000 people of whom 625,000 were Jews. $^{3}$

Failing to resolve the conflicting moral-legal claims of the Palestinians and the Zionists, which overtime had become

1 For text of the British Mandate over Palestine see J.C. Hurewitz (ed.), Diplomacy in the Near and Middle East: A Documentary Record 1914-1956 (New York: D. Van Nostrand Company, Inc. 1956), pp. 106-111.

2 For text of the Balfour Declaration see Ibid., pp. 25-26.

3 Ellis, Harry B., The Dilemma of Israel. (Washington, D.C.: American Enterprise Institute for Public Policy Research, 1973), p. 7. 
political issues as well, Britain turned over the whole Palestine question to the UN. The eleven nation United Nations Special Committee on Palestine recommended the partitioning of $\mathrm{Pa}$ lestine into an Arab state, a Jewish state, and an internationalized Jerusalem. The UN General Assembly edopted the notion of partition on November 29, 1947.4

Immediately war ensued between the Palestinians and the Zionists. On May 15, 1948, the proclamation for the establishment of the state of Israel was issued. The involvement of neigbouring Arab states in support of Palestinian people catapulted the conflict in Palestine between the rival nationalisms into a contest between the Arab States and Israel.

The outcome of the Arab-Israel war of 1948 produced farreaching modifications in the original UN partition plan. The Palestinian Arab State envisaged by the plan failed to emerge. The armistice agreements between Jordan and Israel, and between Egypt and Israel of April 1949 and February 1949 respectively, gave Israel some 2,500 square miles which she formally annexed to the 5,600 square miles allotted to her by the partition plan. Tranjordan acquired 2,200 square miles, which she formally annexed transforming herself into the state of Jordan. Egypt retained control of the Gaza Strip, some 135 square miles. ${ }^{5}$

The non-materialization of the Palestinian state produced major reshuffling of Palestine's population. Chased by the Irgun terrorists, over 700,000 Palestinian Arabs fled from their homeland: Lebanon received 80,000, Jordan 400,000, Syria 70,000 and Gaza Strip 150,000. Some 120,000 remained under Israeli control. $^{6}$ The UN General Assembly resolution of December 1948, declared the expelled Palestinians as refugees, with a right to return or compensation.

The Middle East war of June, 1967, brought about further territorial and demographic changes. Israeli forces captured the

4 For the text of the United Nations General Assembly resolution on the Partition of Palestine see J.C. Hurewitz, op. cit., pp. 281-295.

5 Safran, Nadav, From War to War: The Arab-Israeli Confrontation 1948-1967 (New York: The Bobbs-Merrill Company. Inc. 1969), p. 33. 6 Ellis, Harry B., op. cit., p. 7. 
Golan Heights, the West Bank, the Gaza Strip and the Sinai Peninsula from the Arabs, placing 1,000,000 Palestinians under the control of the occupying forces. The number of Palestinians living in Arab states crossed the mark of 1,000,000.

Te Zionist expansionism has rendered more than a million Palestinian people homeless. In the West Bank and the Gaza Strip about a million have been placed under the direct control of Israel.

\section{ii. Israel and the Occupied Territories}

The occupying power of Palestine, Israel, is a parliamentary democracy. It claims to maintain high standards of "justice" and civilized life.

The occupied territories are under military government. Armed forces, rather than civilians are responsible for law enforcement and public security. The residents of the West Bank and the Gaza Strip are largely subject to military orders, which deny most of the human rights to the Palestinian people. The government of Israel has consistently violated the Fourth Geneva Convention of August 12, 1949, pertaining to the protection of civilian population under military rule. Rather, she adamantly maintains that these territories are not within the purview of the said convention.

The Palestinian people living in the West Bank and the Gaza Strip enjoy very little of normal civilian life. Arab newspapers are published under strict censorship. There is no freedom of speech and expression. Municipal elections were permitted in 1972 and 1976, and the one scheduled for spring 1980 were postponed indefinitely. Beyond this, political activity and organisation are banned.

The occupying authorities have increasingly applied stringent measures toward the Palestinian people. Israeli interrogators routinely ill-treat and often torture Arab "security suspects". Torture is used to extract information as well as to pacify occupied territores. The purpose appears to be to bring home to the Palestinian people in the occupied territories that it is least painful to behave passively. 
The Palestinian people in the occupied territories have been subjected to inhuman and degrading treatment or punishment, including deportation. The severity and frequency of such occurrences have increased following the death of 6 Jewish settlers in Hebron, on May 2, 1980. Twice severe curfews were imposed in Hebron, causing extreme hardships to the residents. Males in villages and refugee camps have been rounded up and held outdoors for extended periods of time as a form of general punishment against the inhabitants. The Mayors of Hebron and Halboul and the Qadi of Hebron were deported to Lebanon on charges of inciting people to violence. ${ }^{7}$

Excessive force has been used to quell or disperse protest demonstrations. In November 1980, troops deliberately fired at the legs of demonstrating youths and wounded 16 boys and girls. ${ }^{8}$

The Palestinian people have been subjected to administrative detentions in gross violation of the Fourth Geneva Convention under which administrative detention is not permissible beyond one year from the "general close of military operations." Though administrative detainees have recourse to appeal, it is. rarely exercised, as appeals have never resulted in a reversal of the decision of the military authorities.

Alleged security offenders are tried by the military courts. Though the accused can engage a counsel for his defence, the convictions are mostly based on confession obtained through coercion and torture. ${ }^{9}$ No appeal against the military court's verdict is possible.

The military authorities enter private homes and institutions in pursuit of security objectives. During May-June 1980 crackdown, several breakages, despoliations and beatings took place. Settlers taking advantage of the situation engaged in vandalism and looting. The soldiers plundered the homes during a military search of the village of Silvad in December $1980 .{ }^{10}$ In vio-

7 U.N. Chronicle, July, 1980, p. 6.

\& Department of State, Country Reports on Human Rights (Washington, D.C., Government Printing Office, 1931), p. 1002.

9 Insight Team of The Sunday Times, Israel and Torture (Washington, D.C.: Free Palestine Press, 1977), pp. 19-20.

10 Department of State, op. cit., p. 1005. 
lation of the Fourth Geneva Convention the houses of individuals, believed to have been involved in terrorism, have been demolished or sealed up, and families displaced. Between July 1967 and August 1971, Israel demolished 16,212 homes and deported 1,130 known "agents of subversion" since 1967.11 At least 23 homes were demolished in 1980, and at least six other homes were sealed up on security grounds. Near the site of the May 2, 1980 attack, Israeli authorities blew up a number of commercial establishments. ${ }^{12}$

Extremist Israelis frequently indulge in terrorist acts against the Palestinian people. On June 2, 1980, "the Mayors of Ramallah were maimed by bombs allegedly set for them by Jewish extremists." 13

Israel has restricted economic development of the occupied territories on both commercial and political grounds. She is keeping the West Bank and the Gaza Strip as captive markets. In contravention of the Fourh Geneva Corvention's Article 49, Israel has established more than 100 non-military settlements in the West Bank and the Gaza Strip. Land appropriations for settlements have adversely affected the livelihood of many Arabs, compelling them to quit farming and becoming day labourers. Palestinian agriculture and livestock has been adversely affected due to the exploitation of limited water resources in the West Bank by the Jewish settlers.

The occupying authorities closed several schools, including Bir Zeit University for extended periods. In July 1980, the military governor assumed the power to dismiss university students, bar professors and revoke university charters.

There policies and practices of Israel toward Palestinian people clearly demonstrate the degree to which the provisions of the Fourth Geneva Convention and mutually agreed upon Human Rights are being violated by Israel in the occupied territories.

Having discussed the background of the problem, the problem of the Palestinian people's human rights and the Israeli vio-

11 Insight Team of the Sunday Times, op. cit., p. 18.

12 Department of State, op. cit., p. 1005.

13 Ib.d., p. 1006. 
lations of human rights of the Palestinian people, in the following section it is intended to explain the framework of Human Rights as well as the efforts made by the world body to enforce the same in respect of the Palestinian people.

II. Human Rights and the UN Initiatives in Respect of the Human Rights of the Palestinian People

\section{i. Interpretation of the Concept of Human Rights}

The issue of human rights has assumed increasing importance in the past one century or so. Slavery has been abolished. Rights of ethnic, linguistic and religious minorities are protected. Acts of barbarity and genocide on the subject people do not go unnoticed, unchallenged and unreprimanded.

The concept of human rights is understood differently by people pursuing different socio-economic goals. In the West the emphasis is on the political dimension, i.e., the right to vote and hold public office, rights of freedon of speech and assembly - as well as personal - protection against arbitrary arrest, imprisonment and fair public trial. In the developing countries the achievement of economic and social rights, such as the meeting of basic human needs for adequate food, clothing and shelter takes precedence over political rights like share in the political process. Communist doctrine does not confer individual rights. Human rights are defined collectively in terms of the needs of the state which are considered paramount.

Traditionally, national governments have been considered responsible for ensuring proper enjoyment of and protection against any violation of human rights is the responsibility of the world community has brought in international organization to achieve this end. Human rights provisions have been included in the UN Charter which specifically makes mention of the protection of human rights. The preamble reads:

We the people of the United Nations determined... to affirm faith in fundamental rights, in the dignity and worth of the human person, in the equal rights of men and women and of nations large and small...

On the purposes of the establishment of the UN Article I states: 
...To achieve international cooperation in solving international problems of an economic, social, cultural or humanitarian character, and in promoting and encouraging respect for human rights and for fundamental freedoms for all without distinction as to race, sex, language, or religion...

And article 55 emphasizes:

With a view to the creation of conditions of stability and well-being which are necessary for peaceful and friendly relations among nations based on respect for the principle of equal rights and self-determination of peoples, the United Nations shall promote

Universal respect for, and observance of human rights and fundamental, freedoms for all without distinction as to race, sex, language, or religion.

The UN Commission on Human Rights drew up a Universal Declaration of Human Rights adopted by the General Assembly in 1948. The thirty articles of Declaration cover the full range of civil, political, economic, social and cultural rights. The General Assembly proclaimed it "Common standards of achievement in human rights for all peoples of all nations". It is indubitably an authoritative interpretation of the human rights provisions of the UN Charter and is the basis for most of the subsequent UN actions in the field of human rights.

\section{ii. United Nations Initiatives and the Human Rights of the Palestinian People}

Actualization of the human rights, as embodied in the UN Charter and the Universal Declaration of Human Rights, is the responsibility of the General Assembly, the Security Council, the Economic and Social Council and their subsidiary bodies. The UN organs have taken certain concrete actions in respect of the human rights of the Palestinian people. The same are briefly discussed below.

The Human Rights of the Palestinian people were spelled out, for the first time, in the General Assembly resolution 3236 of November 22, 1974. ${ }^{14}$ The resolution is a major reassertion of the fundamental rights of the Palestinian people. It defines,

14 U.N. GAOR, Supp. 31, p. 4. 
in the operative para, the inalienable rights of the Palestinian people as follows:

right to self-determination without external interference, right to national independence, right to sovereignty, right of return, right to regain all those rights by all means and the right to be represented as a principal party in the establishment of a just and durable peace in the Middle East.

An important implication of the General Assembly resolution is that it legitimizes armed struggle, by the Palestinian people, against the occupying power to liberate their homeland.

In the following years the General Assembly repeatedly reaffirmed these inalienable rights of the Palestinian people in its resolutions 3376 November 10, 1975; 31/20 ABC November 24, 1976, 32/40 AB December 2, 1977, 33/28 ABC December 7, 1978; 34/65 December 19, 1979; and 35/169 A December 15, 1980 under the agenda item; question of Palestine.

Concrete measures were initiated by the General Assembly in its thirtieth session (1975-76) in the direction of implementation of its resolution in respect of the rights of the Palestinian people. One, by its resolution 3375, the Security Council was people to exercise its rights. Two, by its resolution 3376 the Committee on the Exercise of the Inalienable Rights of the Palestinian people was set up and entrusted with the task of formulating a programme of implementation of its resolution 3236 of November 22, 1974, and thereby enabling the Palestinian people to exercise its rights contained in this resolution. The Committee was specifically to maintain international concern for progress toward a just solution of Palestine problem.

The Committee submitted its report to the General Assembly on July 21, 1976, making recommendations on the modalites for the implementation of the exercise of the inalienable rights of the Palestinian people..$^{15}$ It proposed a two-stage plan for the return of all the Palestinian people to their homeland. In stage one the Security Council resolution 237 (1967) was to be implemented. The Palestinian people, displaced as a result of the 1967 war, were to return to Palestine with the assistance of International Committee of the Red Cross and/or United Nations

15 UN Doc. A/31/35. 
Relief and Work Agency. Stage two was to be carried out through the implementation of General Assembly resolution 194 (1948) pertaining to the rights of the refugees of return or compensation. The Palestine Libration Organization as the interim representative of the new Palestinian entity, as well as other concerned states were to be associated with this operation. Following guidelines were laid down by the Committee for the establishment of an independent Palestinian entity.

1. The Security Council should establish a timetable for the complete withdrawal of Israel from the territories occupied in 1967 war.

2. The Security Council should provide temporary peacekeeping forces to facilitate the process of Israeli withdrawals.

3. The UN should take over all evacuated territories to be handed over to PLO as the interim representative of the Palestinian people.

4. Upon the establishment of an independent Palestinian entity, the UN in cooperation with the states involved and the Palestinian people, should make necessary arrangements for the full implementation of the inalienable rights of the Palestinian people, the resolution of outstanding problems and the establishment of a just and lasting peace in the region.

Persuant to General Assembly resolution 3375, the Security Council, in 1976, debated the issue of political rights for the Palestinian people. The draft resolution introduced by six nonaligned countries expressly affirmed the inalienable rights of the Palestinian people, as proclaimed by the General Assembly. It stated that for a just and lasting peace Israel withdraw "from all the Arab territories occupied since June 1967". ${ }^{16}$ The Security Council failed to adopt it because of the United States veto. Under the agenda item "question of the Exercise by the Palestinian people of its Inalienable Rights" the Security Council again discussed the issue of Palestinian rights in June 1976, ${ }^{17}$

16 For text of the draft resolution see U.N. Doc. S/11940.

17 U.N. Doc. S/12119 of June 29, 1976. 
and October $1977,{ }^{18}$ but again the draft resolutions were killed because of the United States' negative vote.

In view of the importance of self-determination, as a basic human right and as the prerequisite for the exercise of all other human rights, the Commission on Human Rights adopted two resolutions in 1978. The Commission in its resolution 2 of February 14, 1978, entitled "The Right of Peoples to Self-Determination and Its Application to Peoples under Colonial or Alien Domination or Foreign Occupation" affirmed the inalienable rights of the Palestinian people to self-determination without external interference and the establishment of a fully independent and sovereign state in Palestine". It further affirmed their right to return to their homes from which they have been uprooted and displaced. It called for a return of all Palestinian refugees as a component of their right to self-determination and recognized their right to fight for their rights by all means. ${ }^{19}$ In resolution 3 of February 14, 1978, under the same title, the Commission reaffirmed the inalienable rights of the Palestinian people to self-determination, national independence, territorial integrity, national unity and sovereignty without external interference. ${ }^{20}$

In December 1978, the General Assembly in its resolution 33/29 called for a comprehensive settlement of the Middle East problem, in which the Palestinian people attained all its inalienable national rights. It demanded Israel's withdrawal "from all the occupied Palestine and other Arab territories. ${ }^{21}$ In resolution 33/28 AC of December 7, 1978, the General Assembly asked the Committee on the Exercise of the Inalienable Rights of the Security Council to take a decision on the Committee's recommendations; and asked the Secretary General to ensure that the Special Unit on Palestinian Rights continue to discharge the tasks assigned to it by the General Assembly resolution 3328 AC. It emphasized the need for "full attainment and exercise of the inalienable rights of the Palestinian people, including the

18 U.N. Doc. S/PV. 2040 of October 27, 1977.

19 Commission on Human Rights, Report on the 34th Session, February 6 - March 10, 1978, pp. 104-5.

20 Ibid., p. 106.

21 U.N. Chronicle, February, 1979, p. 30. 
right to return and the right to national independence and sovereignty in Palestine, with the participation of Palestine Liberation Organization. ${ }^{22}$

At the request of the Chairman of the Committee on the Exercise of Inalienable Rights of the Palestinian people, the Security Council met on April 30, 1980, to consider the question of continuing violation by Israel of the inalienable rights of the Palestine people as well as the recommendations of the Committee endorsed by the General Assembly. However the draft resolution introduced by Tunisia reaffirming the rights of the Palestinian people to exercise their inalienable national right of self-determination, including the right to establish an independent state in Palestine, the right to return home, could not be adopted because of the United States' veto. ${ }^{23}$

The General Assembly, in its resolution 35/169A on December 15, 1980, deplored that the Palestine problem was still unresolved. It reaffirmed that the goal of attainment of just and lasting peace in the Middle East could not be realized without ensuring the inalienable rights of return and the right of self-determination, national independence and sovereignty in Palestine for the Palestinian people. ${ }^{24}$

The UN has been concerned with the socio-economic and cultural rights of the Palestinian people. The UN Secretary General's report of October, $1977,{ }^{25}$ led to the adoption of General Assembly resolution 32/161 of December 19, 1977, specifying the following economic rights of the Palestinian people. ${ }^{26}$

1. The right of the Arab states and peoples whose territories are under Israeli occupation to full effective sovereignty and control over their natural and all other resources.

2. The right of the Arab states and peoples to the restitution and full compensation for the exploitation, depletion, loss and damages of their natural, human and all other resources.

22 U.N. Chronicle, February, 1979, p. 33.

23 U.N. Chronicle, June, 1980, p. 19.

24 U.N. Chronicle, January, 1981, p. 10.

25 U.N. Doc. A/32/204 October 14, 1977.

26 Previous General Assembly resolutions on the subject are: No. 31/ 196 December 21, 1976; No. 3516, December 15, 1975; and No. 3336 December 17, 1974. 
The General Assembly has critized and condemned Israeli policy of establishing settlements in the occupied territory, which has worse economic and social consequences for the Palestinian people. It set up a Special Committee to Investigate Israeli Practices Affecting the Human Rights of the Population of occupied territories by its resolution 2443 of December 19, 1968. The annual reports of the Committee provide wealth of information on Israeli breaches of the Fourth Geneva Convention, August 12, 1949.

Our discussion of the UN role for the restoration of the rights of the Palestinian people, clearly brings out the following two points:

1. The world community has not remained indifferent to the plight of the Palestinian people living in the occupied territories. It is now almost a decade that the concern has been expressed in clear terms for the restoration of the inalienable rights of the Palestinian people through the resolutions adopted by the General Assembly, every year.

2. The record of the two main organs of the UN - the General Assembly and the Security Council - with respect to the restoration of the rights of the Palestinian people should be of special interest to the students of International Organization as well as cause for concern to those who are interested in a just and lasting peace in the Middle East. While the representative body of all peoples of all nationsthe UN General Assembly-has supported the cause of uprooted and oppressed Palestinian people, the Security Council, the preservative of big power interest has failed to translate the General Assembly concern for the lamentable plight of the Palestinian people, into some meaningful action.

From the foregoing discussion, it would be evident that though many measures had been initiated by the UN to implement the provisions of its Charter in respect of human rights and of the Universal Declaration of Human Rights in the case of the Palestinian people, nothing has come about so far. The resolutions of the General Assembly and of the Commission on Human Rights have turned out to be nothing more than nice documents wanting implementation. 
In the next section we intend to shift the focus of our discussion to the role of superpowers on the question of human rights for the Palestinian people.

\section{Superpowers and the Human Rights of the Palestinian People}

Factually speaking, both the United States and the Soviet Union cast their votes, in the General Assembly in November 1947, for the creation of the Zionist state in Palestine. They conferred recognition of statehood on it in the immediate aftermath of the issuing of the proclamation of its establishment on May 15, 1948.

The creation of the state of Israel in Palestine rendered thousands of the Palestinian people homeless. Although the Palestinian problem is there since 1948, the superpowers, by an large, did not show much concern for the plight of these displaced persons till the morrow of the Arab-Israel war of June, 1967. Apparently, they were content with the refugee status of the Palestinian people till the issuing of the National Charter by the PLO in July, 1968, and the Jordanian crisis of September, 1970. They regarded them mainly a UN responsibility, with a right to choose between return or compensation.

The shock of the events of 1967 politicised the Palestinian problem and converted the Palestinians from refugees to a people with national rights. Hijackings, attacks on persons and places brought them in sharp focus of world attention, including that of the superpowers.

\section{i. The United States}

The United States feels a strong moral and political conmitment to the survival and political independence of Israel. Israel's security and well-being are a top priority concern of policy makers in the United States. The United States policy toward the restoration and realization of the Human Rights of the Palestinian people has been mostly guided and dictated by her commitments to Israel.

The United States has so far refused to recognize the PLO; the spearhead of the Palestinian people's struggle to liberate 
Palestine and establish their independent sovereign state. Henry Kissinger, the Secretary of State of America, capitulated on the issue of Palestinian participation in Geneva Peace Conference in December, 1973, when Israel refused to go to Geneva if the Palestinians were present.

The United States-Israel pact on Geneva, initialed at the time oî the signing of Sinai II, by Egypt and Israel, bound Washington to continue to adhere to policy with respect to PLO whereby it will not recognize or negotiate with the PLO, ${ }^{27}$ and promised Israel the right to veto the participation by the $\mathrm{PLO}$ in any future Peace Conference in Geneva. In the United States-Israeli Memorandum of Agreement, it was agreed that the United States would prevent efforts by others to bring about consideration of proposals detrimental to the interest; of Israel. ${ }^{28}$

These commitments by the United States have led to Washington's unqualified diplomatic and political support to Israel on all issues including the question of human rights of the $\mathrm{Pa}$ lestinian people. This has been both inside and outside the UN. The United States has cast mostly negative votes on draft resolutions introduced in the General Assembly, opposed by Israel. In the Security Council the United States has consistently vetoed almost all draft resolutions impinging upon Israel.

The United States cast negative vote in the Security Council and killed draft resolution pertaining to the rights of the Palestinian people introduced by six-aligned countries in January, 1976. ${ }^{29}$ The draft resolution contained provisions affirming the inalienable rights of the Palestinian people. It demanded Israeli withdrawal from the Arab territories as a prerequisite of just and lasting peace in the Middle East. This performance was repeated by the United States in June, 1976, and October, 1977, when the issue of Palestinian rights under the agenda item "The Question of the Exercise by the Palestinian People of its

27 For text of United States - Israel Pact on Geneva see Now York Times, September 18, 1975.

23 For text of Memoranda of Agreement see Wash ngton Post, Septembor 16, 1975.

29 For text of the draft resolution see U.N. Doz. S/11040. 
Inalienable Rights" came for discussion before the Security Council. ${ }^{30}$

A draft resolution, pertaining to the rights of the Palestinian people introduced by Tunisia in the Security Council, was vetoed by the United States on April 30, 1980. The draft resolution had demanded an affirmation from the Council of the inalienable rights of the Palestinian people and the establishment of an independent sovereign state of Palestine. ${ }^{31}$

The United States has made huge inputs of economic and military aid to Israel. ${ }^{32}$ (As is clear from Table 1). This has made Israel intransigent and obdurate. The American policy makers say that the aid is aimed at making Israel flexible in her policies through strengthening her security and economy. But, in actual fact, the more strong militarily and economically the Israelis become, the more obstinacy, intransigence and obduracy they exhibit in their policies toward the Palestine question.

The receipt of most advanced weapon system from the United States has given the Israelis a feeling that they can sit tight, perpetuate occupation and thereby continue trampling the rights of the Palestinian people of the West Bank and the Gaza Strip with impunity. They have developed an aura of conquerors about themselves. The United States has made Israeli defence virtually impregnable and offense uninterceptable through a supply of most advanced weapons in her arsenal and by creating a strategic weakness in the Arab front through the withdrawal of Egypt as a result of the signing of the EgyptIsrael Peace Treaty of March 1979.

This, by and large, the United States policies towards the Middle East and its problems are an obstruction to the materialization of the rights of the Palestine people. The United States has critized Israel's settlement policy in occupied territories as immoral and illegal. She has objected to the annexation of Jerusalem, occasionally has blamed Israel for ill-treatment

30 For text of the draft resolution see U.N. Doc. S/12119.

31 For text of the draft resolution see U.N. Doc. S/13911.

32 Table I gives details of official Economic and Military aid to Israel over the past three years. 
TABLE - I

U.S. LOANS AND GRANTS TO ISRAEL (U.S. FISCAL YEARS - MILLIONS OF DOLLARS)

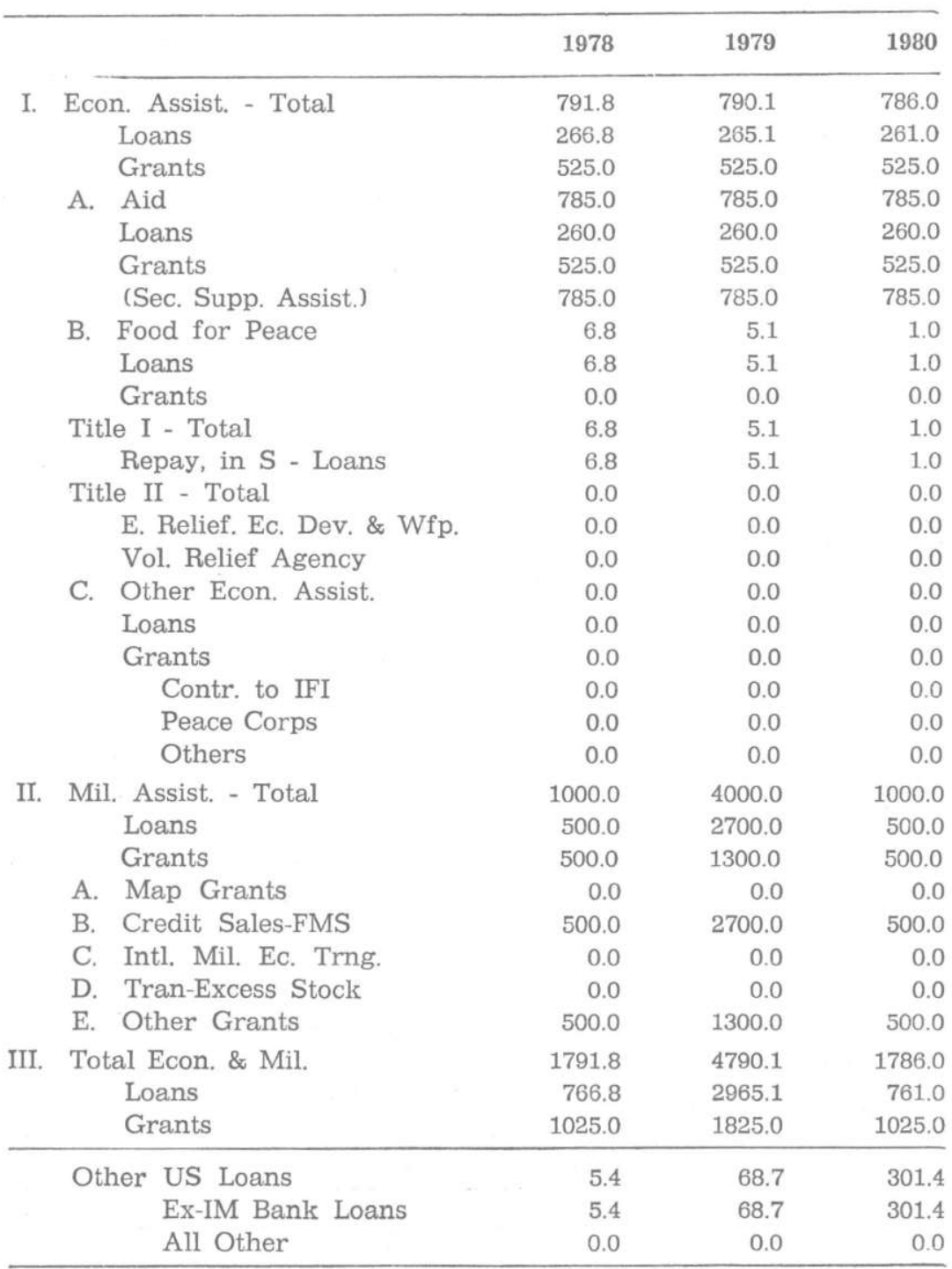

Source : Department of State, Country Reports on Human Rights, 1980. The Table does not include huge sums that are collected in the United States through tax-free 'Charity' and other contributions to fund for Israel and the proceeds from the sale of Israeli bonds in America. 
of the residents of ozcupied territories, but the impact of her overall policies has been deterimental to the restoration of the rights of the Palestinian people.

In analyzing the role of the successive Administrations in Washington toward the rights of the Palestinian people, one wonders why a country whose internal policies on human rights are so praise-worthy has not reflected the same in the case of the Palestinian people. Apparently, one plausible interpretation of this is the United States government's total commitment to ensure the continued existence of Israel under political pressure produced within the country.

\section{ii. The Soviet Union}

From the spring of 1968, the Soviet mass media and the government increased their interest in the Palestinian people and the PLO. Contacts were maintained with PLO through Egypt. In the aftermath of June, 1967 war, the Soviet Union became sympathetic to the liberation struggle of the Palestinian people. Yasir Arafat, the Chairman of PLO, paid his first visit to Moscow in 1972.

The Soviet Union, in the post-October, 1973 Arab-Israel war period, began to insist that any political solution to the Arab-Israel conflict must include the fulfilment of the national legitimate rights of the Palestinian people. It implied that after the Israeli withdrawal a Palestinian sovereign entity should be established in the West Bank and in the Gaza Strip.

Moscow increasingly sought to prove the indispensability of the PLO in any Arab-Israel settlement. At the same time the Soviet Union tried to augment the political strength and significance of PLO.

In a joint communique, on November 15, 1973, the Soviet Union and Yugoslavia endorsed the Palestinian people's demand for a national entity. ${ }^{33}$ And in June 1974, the Soviet sources stated clearly that "the national legitimate rights of the $\mathrm{Pa}$ lestinians" which Moscow supported, meant an independent state..$^{34}$

33 Foreign Broadcast Information Sorvice (hereafter FBIS), November 16, 1973.

34 FB-S, June 5, 1974 
The Soviet Union, with a view to facilitate Palestinian participation at Geneva, demanded a new interpretation of the Security Council resolution 242. They wanted to make it acceptable to the Palestinian people. An article in Izvestia said, for example, that the Geneva Peace Conference would convene with the participation of the PLO only on condition that the Palestinian question be defined "as a political question, as a question of security, the lawful national rights of the Arab people of Palestine and is not confined to the refugee problem." 35

Arafat, during his November 1974 visit to Moscow, officiaily met Prime Minister Alexie Kosygin. TASS announcement of the meeting between Kosygin and Arafat was worded as if this were the meeting between two heads of government. ${ }^{36}$ The joint communique issued at the end of the visit, pledged the Soviet Union's continued support for "the struggle of the Arab people of Palestine, for their legitimate rights, including their inalienable rights to self-determination and the creation of their own national home up to the formation of their statehood." 37

The Soviet Union has consistently cast positive votes on all draft resolutions affirming the inalienable rights of the Palestinian people, before the General Assembly or the Security Council. She has been very critical of the United States negative votes in the General Assembly and Washington's use of veto on draft resolutions before the Security Council demanding the materialization of the inalienable rights of the Palestinian people, including the right to establish an independent sovereign state.

A question may be asked here whether the Soviet Union's stand on the issue of human rights for the Palestinian people is based on a genuine concern for the Palestinians or on political expediency with eye on future in respect of Middle East region. Probably both considerations are there. Undoubtedly

35 Quoted by Baruch Gurewitz, "The Soviet Union and the Palestinian Organizations" in Yaacov Ro'i (ed.), The Limits To Power: Soviet

Policy in the Middle East. (London: Biddles Ltd., 1979), p. 262.

36 FBIS November 29, 1974.

37 FBIS December 9, 1974. 
the Soviet Union's efforts to champion the cause of the Palestinians at various forums are noteworthy. However, the motives underlying this are not very clear; particularly when one looks into her internal record on human rights. Thus, one may be forced to conclude that the Soviet position on the question is not entirely free from political overtones.

Our discussion of superpower's role in respect of the restoration of the rights of the Palestinian people may be concluded with the note that nothing substantial can be expected out of the superpowers' activities. This leads us to the logical question, that is, what should be done to redeem the situation? Next section of the article is devoted to answer this question by way of advancing a few suggestions.

\section{SUGGESTIONS FOR FUTURE COURSE OF ACTION}

Despite the UN General Assembly's repeated annual declarations that the Palestinian people have national rights, such as the right to self-determination leading to the establishment of a sovereign political entity, nothing has come about so far. The main factor has been the Security Council's inability to act. The General Assembly's formal resolutions could not be converted into a plan of action for the restoration of the rights of the Palestinian people because of the unqualified support that comes from the United States for Israel. Consequently, the General Assembly call to the Security Council to apply canctions against Israel has not found unanimously accepting ears in the Security Council circles.

What can be done under these circumstances to materialize the human rights of the Palestinian people? The following suggestions may be worth pondering in this regard:

1. The PLO, as a coordinating and integrating force for the various groups and opinions within the Palestinian people, should act to galvanize all possible support that can accrue to it so as to strengthen itself to achieve the goal for which it has been established. A two-pronged action is likely to help achieve this goal. On the one hand at the organizational level, it should pay greater attention to internal cohesion and unity. Common bonds of indentity-background, ethni- 
city, socio-economic geographic, cultural etc. - and destiny the creation of sovereign independent Palestinian stateamong the Palestinian people should be emphasized and propagated. Differences - organizational and purpositive in the ranks of Palestinian people should be amicably settled because internal dissension and absence of unity in thought and organization are likely to hamper all plans of goal attainment. Unity and cohesion will help generate an indigenous force that will have to be reckoned with by all related to this problem. On the other hand, efforts should be directed to tap all sources of strength - political, diplomatic, economic and military - at the regional as well as international levels. Proper propagation will build image and enhance the prestige of the PLO as the sole representative body of the Palestinian people and augment its power to influence the decisions of international actors involved in the question of Palestine.

2. Greater attention should be paid and utilization be made of the alternative forums, for example, the Non-Aligned Movement and the Organization of Islamic Conference. They constitute a majority in the global political structure; NAM has 94 members and OIS strength stands at 42 states.

Moreover, most of the members of these organizations have experienced in the past the problem of deprivation of human rights; therefore, full cooperation and solid support can be expected of them. They have already taken up the cause of the Palestinian people and pressure on the superpowers from the above countries will hopefully lead to new initiatives that may force Israel to submit to the legitimate desires of the world body.

An equally useful weapon may be bringing economic pressure on Israel from the superpowers.

3. The United States should be made to realize that its policy of partial settlement in the Middle East has reached cul de sac and that it has not helped in achieving the goal of a just and lasting peace in the Middle East. Therefore, it must use its economic and military leverage with Israel to achieve a comprehensive settlement that takes into account all problems and all parties to the conflict. 
4. The PLO should try to make fuller use of the American media to inform the American people that how a persecuted people, the Jews, have become persecutors and that the successive American Administrations are largely responsible for this. It should be emphasized with them that the ideals of human dignity and honour that they preach and practice within America, should be made available to the homeless Palestinian people.

It is expected that these steps will help arouse moral sense of the American people to neutralize the pressure of Jewish Lobby on the policy makers in Washington.

A situation in which the superpowers begin to look at the question of Palestine without coloured glasses and adopt policy posture on the basis of the merit of the case, both within and without the UN, will help materialize the human rights of the Palestinian people. Predictably in intense awareness about the magnitude of the problems and the potential dangers which permeate the region may produce pressure on Administrations in the United States and the Soviet Union to seek a total settlement of the problem whereby a Palestinian state conferring all the human rights on the Palestinian people will be established.

\section{CONCLUSION}

The Problem of Palestine is festering for the last 33 years and the Palestinian people are languishing for their human rights.

Israel continues to follow a course wherein the Palestinian people suffer a deprivation of their human rights. American military and economic aid has encouraged Israel in the pursuit of this policy and has made her adamant to the extent of flouting world opinion.

The UN has failed as a world body to implement its resolutions that would lead to resolving the issue of Palestinian people. Its efforts at redeeming the Palestinian people's situation has hardly borne any fruits because of American Administration's attitude. Nor has the Soviet policy of coolness to active espousal 
of Palestinian people cause done any good to the Palestinian people.

Since much cannot be expected from the UN or the superpowers, it is advisable to make rigorous use of other forums of opinion, persuasion, and pressure. In this regard, NAM and OIS platforms may prove to be very effective to bring home to Israel and the superpowers the need to act immediately to restore the rights of the Palestinian people. 